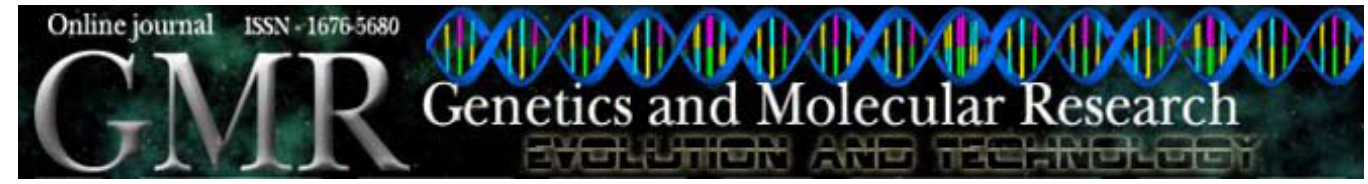

\title{
Hemoglobin polymorphism and hematological profile of Geoffroy's side-necked turtle (Phrynops geoffroanus, Testudines) in the northwestern region of São Paulo State, Brazil
}

C.E.S. Zago ${ }^{1}$, A.L. Ferrarezi ${ }^{4}$, L.D. Vizotto ${ }^{1}$, C. Oliveira $^{2}$, S.R.P. Cabral ${ }^{2}$, S.R. Taboga ${ }^{3}$, G.O. Bonilla-Rodriguez ${ }^{4}$, L.P.R. Venancio ${ }^{1}$ and C.R. Bonini-Domingos ${ }^{1}$

${ }^{1}$ Departamento de Biologia, Laboratório de Hemoglobinas e Genética das Doenças Hematológicas, Instituto de Biociências, Letras e Ciências Exatas, Universidade Estadual Paulista "Júlio de Mesquita Filho", São José do Rio Preto, SP, Brasil ${ }^{2}$ Departamento de Biologia, Laboratório de Anatomia Comparada, Instituto de Biociências, Letras e Ciências Exatas,

Universidade Estadual Paulista "Júlio de Mesquita Filho", São José do Rio Preto, SP, Brasil

${ }^{3}$ Departamento de Biologia, Laboratório de Microscopia e Microanálise, Instituto de Biociências, Letras e Ciências Exatas,

Universidade Estadual Paulista "Júlio de Mesquita Filho",

São José do Rio Preto, SP, Brasil

${ }^{4}$ Departamento de Química e Ciências Ambientais,

Laboratório de Bioquímica, Instituto de Biociências, Letras e Ciências Exatas, Universidade Estadual Paulista "Júlio de Mesquita Filho",

São José do Rio Preto, SP, Brasil

Correspondence author: C.R. Bonini-Domingos

E-mail: claudiabonini@sjrp.unesp.br

Genet. Mol. Res. 9 (2): 721-726 (2010)

Received December 17, 2009

Accepted January 28, 2010

Published April 20, 2010

DOI 10.4238/vol9-2gmr731

ABSTRACT. Complete blood counts and hemoglobin isoform data were gathered from 36 specimens of the turtle species Phrynops geof- 
froanus from the northwestern region of São Paulo State, Brazil. They were collected in an urban area. The hemoglobin profiles were obtained after red blood cell lysis and by electrophoretic migration in alkaline $\mathrm{pH}$, acid $\mathrm{pH}$, and neutral $\mathrm{pH}$ buffer. The hemoglobin components were confirmed using high-performance liquid chromatography (HPLC). Erythrogram analysis included hematocrit, total hemoglobin concentration, total red blood cell count, and red blood cell indices. The leukogram included a total white blood cell count and a calculation of the percent values of neutrophils, lymphocytes, monocytes, basophils, eosinophils, heterophils, and azurophils. HPLC analysis revealed three hemoglobin components; the first with a concentration of $5.5 \%$, the second was a major component with an average concentration of $67.1 \%$, and the third with a concentration of $28.5 \%$. The hematological profile obtained for these specimens allowed us to establish a pattern for $P$. geoffroanus in São Paulo State Northwestern region. The average hematocrit values were $22.5 \%$ for females and $24.0 \%$ for males. For total hemoglobin, we found average values of $6.66 \mathrm{~g} / \mathrm{dL}$ in females and $7.22 \mathrm{~g} / \mathrm{dL}$ in males. The number of white blood cells was $2725 \times 10^{3} / \mu \mathrm{L}$ for females and $2775 \times 10^{3} / \mu \mathrm{L}$ for males. There was a predominance of heterophils, eosinophils, and monocytes in both sexes. No significant differences were found between males and females for hematological profile. The hematological results were compared to literature data for other Chelonia. They were similar to what is known for fresh water turtles.

Key words: Phrynops geoffroanus; Hemoglobin polymorphism; Hematological profile

\section{INTRODUCTION}

Physiological studies of wild animals that are kept in captivity or have been recently captured are very important for obtaining details about the nature of the species in question, which can be used as a diagnostic tool. Blood is one of the first systems to be studied. It has the ability to transport gases (primarily oxygen) and nutrients, and also to eliminate metabolic waste.

A complete blood count consists of an evaluation of a variety of parameters that allow us to obtain information about the general state and health of the animal, and that aid in the identification of pathologies, particularly those related to volemia and infections (GarciaNavarro and Pachaly, 1994). When compared to other vertebrates, there is little information available in the literature about the hematology and the hemoglobin profiles of reptiles (GarciaNavarro and Pachaly, 1994; Brites and Rantin, 2004). Phrynops geoffroanus, commonly known as Geoffroy's side-necked turtle, is a small animal, with the male averaging approximately 21 $\mathrm{cm}$ in length and the female averaging $35 \mathrm{~cm}$. They are frequently found in rivers, lakes, and ponds with slow currents, and have a wide distribution, including South American countries as Colombia, Venezuela, Guyana, the far southern region of Paraguay, and the southeastern, central-western, and northeastern regions of Brazil (Pritchard, 1979; Ernest and Barbour, 1989). 
The aim of this study was to establish the hemoglobin polymorphisms and the hematological profile of $P$. geoffroanus in the northwestern region of São Paulo State. In this region, $P$. geoffroanus is usually found in rivers and lakes, which affects the method of obtaining data on the biology of this animal.

\section{MATERIAL AND METHODS}

São José do Rio Preto is located in the southeast region of Brazil, at the following geographic coordinates: $20^{\circ} 49^{\prime} 12^{\prime \prime} \mathrm{S} 49^{\circ} 22^{\prime} 44^{\prime \prime} \mathrm{E}$. The city is physically divided by the Preto River and its tributaries, including the Piedade Stream and the Felicidade Stream. The Preto River is approximately $120 \mathrm{~km}$ long, and is a tributary of the Turvo River, which flows into the Grande River, and is a component of the Turvo-Grande Basin.

The animals were collected from the Felicidade Stream, which is in an urban area of São José do Rio Preto. They were then taken to the animal facility of UNESP-IBILCE, where sex, length and weight were determined. The animals were then isolated from the other animals in the animal facility in order to prevent stress.

The blood samples of the 36 animals (20 females and 16 males) were obtained using cardiocentesis. The samples were then conditioned in tubes containing heparin as an anticoagulant, and were processed in less than $24 \mathrm{~h}$ in order to avoid the formation of cell fragments, resulting in a more intense staining of the smear (Canfield, 1998). None of the animals were sedated in order to avoid additional stress, and also to avoid the interference of anesthetic drugs on the blood parameters, following Brites and Ratin, 2004. The project was approved by IBAMA and the National Committee of Ethics in Animal Research. In order to obtain hemoglobin components, red blood cells were lysed with water, and the hemoglobin solution purified with chloroform. The migration of the components was observed after electrophoresis at alkaline $\mathrm{pH}$ and neutral $\mathrm{pH}$ in cellulose acetate, and at acid $\mathrm{pH}$ on agarose gels. The components obtained were compared to a human HB AS standard. Afterward, the components were confirmed using high-performance liquid chromatography (HPLC; Bonini-Domingos, 2006).

For the hematological profile analysis, the hematocrit was determined using a high speed microcentrifuge and microcentrifuge tubes. Hemoglobin was determined using Drabkin's solution and readings were taken with a spectrophotometer in visible light. The red and white blood cell counts and the red blood cell indices were determined according to the protocol established by Garcia-Navarro and Pachaly (1994), which relies on a Neubauer chamber and light microscopy. The white blood cell differential count and the thrombocyte count were carried out using blood smears, rapid Panoptic staining, and light microscopy analysis.

Statistical data analysis was performed using the BioEstat 3.0 software. The resulting values were tested and normalized using the Shapiro-Wilk test and homoscedastic distribution. The parametric test used to compare averages was the Student $t$-test, and the non-parametric test used was the Mann-Whitney U-test (Ayres et al., 1998).

\section{RESULTS}

Analysis of hemoglobin polymorphism showed that there were two diffuse components at $\mathrm{pH}$ 8.5. They were the major components with faster migration, faster than human $\mathrm{Hb}$ A. The minor component was similar to human $\mathrm{Hb} \mathrm{S}$. Under electrophoresis at $\mathrm{pH} 7.0$, two 
very similar components were observed. They were essentially indistinguishable and migrated discretely toward the positive electrode. Two distinct components were observed on phosphateagarose gels, $\mathrm{pH} 6.2$, one stayed at origin and the other migrated to the human $\mathrm{Hb} \mathrm{F}$ position. HPLC analysis revealed three hemoglobin components. The first component eluted had a retention time of $2.6 \mathrm{~min}$ and an average concentration of $5.5 \%$. The second was a major component with a retention time of $4.7 \mathrm{~min}$ and an average concentration of $67.1 \%$. The third component had a retention time of $5.02 \mathrm{~min}$ and an average concentration of $28.5 \%$. We did not observe any differences in hemoglobin profile between males and females of the species.

The average hematocrit values were $22.5 \%$ for females and $24.0 \%$ for males. For total hemoglobin, we found average values of $6.66 \mathrm{~g} / \mathrm{dL}$ in females and $7.22 \mathrm{~g} / \mathrm{dL}$ in males. For thrombocytes, we found an average of $12.0 \%$ for females and $16.5 \%$ for males (Table 1 ). The red blood cell count showed average values of $5.9 \times 10^{5} / \mu \mathrm{L}$ for females and $7.4 \times 10^{5} / \mu \mathrm{L}$ for males, with no statistically significant differences between the sexes.

\section{Table 1. Average hematological values in erythrogram of males and females of Phrynops geoffroanus.}

\begin{tabular}{|c|c|c|c|c|c|}
\hline \multirow[t]{2}{*}{ Erythogram } & \multicolumn{2}{|c|}{ Females } & \multicolumn{2}{|c|}{ Males } & \multirow[t]{2}{*}{$\mathrm{P}$} \\
\hline & Mean & SD & Mean & SD & \\
\hline Hematocrit (\%) & 22.5 & 3.99 & 24.0 & 4.10 & 0.1197 \\
\hline Hemoglobin (g/dL) & 6.66 & 2.12 & 7.22 & 1.92 & 0.8297 \\
\hline Thrombocytes (\%) & 12.0 & 8.23 & 16.5 & 6.93 & 0.0852 \\
\hline Red blood cells $\left(\times 10^{5} / \mu \mathrm{L}\right)$ & 5.9 & 205621 & 7.4 & 271716 & 0.0519 \\
\hline MCV (fL) & 32.84 & 7.66 & 32.09 & 7.42 & 0.1567 \\
\hline MCHC (g/dL) & 31.25 & 8.32 & 30.19 & 8.01 & 0.6615 \\
\hline $\mathrm{MCH}(\mathrm{pg})$ & 0.60 & 0.16 & 0.49 & 0.19 & 0.0626 \\
\hline
\end{tabular}

$\mathrm{MCV}=$ mean corpuscular volume; $\mathrm{MCHC}=$ mean cell hemoglobin concentration; $\mathrm{MCH}=$ mean cell hemoglobin.

Similar statistical results were found for the red blood cell indices (mean corpuscular volume, mean cell hemoglobin concentration and mean cell hemoglobin). When compared to the values for $P$. geoffroanus obtained in this study, hematocrit and total hemoglobin values obtained for Chelonia in the literature were similar to some exclusively aquatic species (Table 2).

\begin{tabular}{lccc}
\multicolumn{4}{l}{ Table 2. Hematocrit and hemoglobin values in various species of Chelonia. } \\
\hline Species & Hematocrit (\%) & Hemoglobin (g/dL) & References \\
\hline P. geoffroanus (female) & 22.5 & 6.66 & - \\
P. geoffroanus (male) & 24.0 & 7.22 & - \\
P. geoffroanus (female) & 10.06 & 8.06 & Brites and Rantin, 2004 \\
P. geoffroanus (male) & 8.51 & 7.20 & Brites and Rantin, 2004 \\
Trachemys s. elegans & 26 & - & Moon and Foerster, 2001 \\
Chrysemys picta & 19.8 & - & Moon and Foerster, 2001 \\
Caretta caretta & $25-40$ & - & Moon and Foerster, 2001 \\
Chelonia mydas & $22-45$ & $7.5-12.5$ & Wood and Ebanks, 1984 \\
Chelonia agassizzi (female) & 31 & - & Moon and Foerster, 2001 \\
Chelonia agassizzi (male) & 29 & - & Moon and Foerster, 2001 \\
Dermochelys coriacea & 39 & - & Moon and Foerster, 2001 \\
Lepidochelys kempi & $31-34$ & - & Moon and Foerster, 2001 \\
Chelonoidis c. chilensis (female) & 23 & 10.4 & Troiano and Silva, 1998 \\
Chelonoidis c. chilensis (male) & 22 & 10.1 & Troiano and Silva, 1998 \\
\hline
\end{tabular}

- = Data not provided by the authors. 
A discrepancy was found in the hemoglobin values when comparing specimens from São Paulo and Minas Gerais States (Table 3). The total number of white blood cells was 2725 $\mathrm{x} 10^{3} / \mu \mathrm{L}$ for females and $2775 \times 10^{3} / \mu \mathrm{L}$ for males.

There was a predominance of heterophils, eosinophils, and monocytes in both sexes (Table 4), which diverged from the results found in the literature for other Chelonia (Table 5).

\begin{tabular}{|c|c|c|c|c|}
\hline & \multicolumn{2}{|c|}{ São Paulo } & \multicolumn{2}{|c|}{ Minas Gerais* } \\
\hline & Female & Male & Female & Male \\
\hline Ht (\%) & 22.5 & 24.0 & 10.06 & 8.51 \\
\hline $\mathrm{Hb}(\mathrm{g} / \mathrm{dL})$ & 6.66 & 7.22 & 8.06 & 7.20 \\
\hline $\operatorname{MCV}(\mathrm{fL})$ & 32.84 & 32.09 & 91.56 & 92.44 \\
\hline $\mathrm{MCHC}(\mathrm{g} / \mathrm{dL})$ & 31.25 & 30.19 & 79.44 & 84.31 \\
\hline $\mathrm{MCH}$ (pg) & 0.60 & 0.49 & 93.30 & 113.40 \\
\hline Red blood cells $\left(\mathrm{x} 10^{5} / \mu \mathrm{L}\right)$ & 5.9 & 7.4 & 109.81 & 92.13 \\
\hline White blood cells $\left(\mathrm{x} 10^{3} / \mu \mathrm{L}\right)$ & 2725 & 2775 & $2.24 \times 10^{9}$ & $2.13 \times 10^{9}$ \\
\hline
\end{tabular}

*Brites and Rantin, 2004.

\begin{tabular}{|c|c|c|c|c|c|}
\hline \multirow[t]{2}{*}{ White blood cells } & \multicolumn{2}{|c|}{ Females } & \multicolumn{2}{|c|}{ Males } & \multirow[t]{2}{*}{$\mathrm{P}$} \\
\hline & Mean & SD & Mean & SD & \\
\hline Total leukocyte count $\left(\times 10^{3} / \mu \mathrm{L}\right)^{*}$ & 2725 & 712.64 & 2775 & 996.82 & 0.8361 \\
\hline Neutrophils (\%)* & 2.0 & 0.91 & 3.0 & 1.07 & 0.2791 \\
\hline Lymphocytes (\%)* & 13.5 & 4.86 & 11.0 & 3.34 & 0.1901 \\
\hline Monocytes (\%) & 11.0 & 6.44 & 13.5 & 5.49 & 0.7002 \\
\hline Basophils (\%) & 7.0 & 2.92 & 7.0 & 4.04 & 0.4437 \\
\hline Eosinophils (\%) & 16.0 & 5.30 & 15.5 & 8.11 & 0.7780 \\
\hline Heterophils (\%) & 42.5 & 6.30 & 45.0 & 7.65 & 0.4797 \\
\hline
\end{tabular}

Student $t$-test and Mann-Whitney U-test (*).

Table 5. Comparison of differential leukocyte counts between three Chelonia species.

\begin{tabular}{|c|c|c|c|c|c|}
\hline & $\begin{array}{l}\text { P. geoffroanus } \\
\text { (female) }\end{array}$ & $\begin{array}{l}\text { P. geoffroanus } \\
\text { (male) }\end{array}$ & Chelonia mydas & $\begin{array}{c}\text { Chelonoidis c. chilensis } \\
\text { (female) }\end{array}$ & $\begin{array}{c}\text { Chelonoidis c. chilensis } \\
\text { (male) }\end{array}$ \\
\hline Neutrophils (\%) & 2.0 & 3.0 & 6.0 & - & - \\
\hline Lymphocytes (\%) & 13.5 & 11.0 & 69.0 & 26.0 & 26.0 \\
\hline Monocytes (\%) & 11.0 & 13.5 & - & 5.0 & 5.5 \\
\hline Basophils (\%) & 7.0 & 7.0 & 9.0 & 2.0 & 1.0 \\
\hline Eosinophils (\%) & 16.0 & 15.5 & 14.0 & 31.0 & 32.0 \\
\hline Heterophils (\%) & 42.5 & 45.0 & - & 28.0 & 27.5 \\
\hline Azurophils (\%) & 5.0 & 4.0 & - & 8.0 & 7.8 \\
\hline
\end{tabular}

- = Data not provided by the authors (Moon and Foerster, 2001; Troiano and Silva, 1998).

\section{DISCUSSION}

The first reports of hemoglobin polymorphism in Testudines described the presence of 2 of 5 hemoglobin components in various species, and used low-resolution starch gel electrophoresis (Sullivan and Riggs, 1967). However, electrophoretic migration at alkaline pH permitted to identify only the components with the highest concentrations, and did not demonstrate the separation of minor components. HPLC analysis revealed one major component and two minor components in both males and females of $P$. geoffroanus. There was no evidence of the sexual dimorphism that had been observed in other species. 
The hematocrit values were similar to those observed in freshwater turtles, such as Trachemys scripta elegans and Chrysemys picta, which were described by Moon and Foerster (2001). Saltwater turtles have a higher average value, which may reflect a physiological adaptation to the environment (Moon and Foerster, 2001). The values found for total hemoglobin were similar to those described in the literature for Chelonia mydas and Chelonoidis chilensis chilensi (Wood and Ebanks, 1984; Troiano and Silva, 1998). Hutchison and Szarski (1965) mentioned that geographic location may influence hematological values, particularly red blood cell count. We made the same observation in our study when we compared the results obtained for this species to those obtained by Brites and Rantin (2004) in another region in Brazil.

The average white blood cell count was similar to that of some turtle species, such as Chelonia agassizii and Chelonia mydas, and was higher than those values found for Chrysemys picta and Lepidochelys kempi (Moon and Foerster, 2001). Different values were found for the different types of leukocytes, which is likely a reflection of environmental variations and physiological adaptations.

Although the observed differences in hematological profile between males and females of the species in the northwestern region of São Paulo State were not significant, the disparity between our data and the data in the literature for animals from other urban areas of Brazil suggests that the animals have adapted to the specific urban environments that they inhabit.

\section{ACKNOWLEDGMENTS}

We thank the Brazilian organization, CAPES (Coordenação de Aperfeiçoamento de Pessoal de Nível Superior), for the Master's grant. Additionally, we are thankful to Maria Isabel Afonso da Silva for technical assistance with the CBCs and the collection of the samples and to Danielle Deremo for help with the translation of the manuscript.

\section{REFERENCES}

Ayres M, Junior MA, Ayres DL and Santos AS (1998). Bioestat. 3rd edn. Museu Paraense Emílio Goeldi/Conselho Nacional de Desenvolvimento Científico e Tecnológico (MPEG/CNPq), Manaus.

Bonini-Domingos CR (2006). Metodologias Laboratoriais para o Diagnóstico de Hemoglobinopatias e Talassemias. Editora HN, São José do Rio Preto.

Brites VLC and Rantin FT (2004). The influence of agricultural and urban contamination on leech infestation of freshwater turtels, Phrynops geoffroanus, taken from two areas of the Uberabinha River. Environ. Monit. Assess. 96: 273-281.

Canfield PJ (1998). Comparative cell morphology in the peripheral blood film from exotic and native animals. Aust. Vet. J. 76: 793-800

Ernest CH and Barbour RW (1989). Turtles of the World. Smithsonian Institution Press, Washington D.C.

Garcia-Navarro CEK and Pachaly JR (1994). Manual de Hematologia Veterinária. 1st edn. Livraria Varela Ltda., São Paulo. Hutchison VH and Szarski H (1965). Number of erythrocytes in some amphibians and reptiles. Copeia 3: 373-375.

Moon PF and Foerster SH (2001). Zoological Restraint and Anesthesia: Reptiles, Aquatic Turtles (Chelonians): 2001. International Veterinary Information Service. Available at [http://www.ivis.org]. Accessed August 2009.

Pritchard PCH (1979). Encyclopedia of Turtle. TFH Publication Ltda., New York.

Sullivan B and Riggs A (1967). Structure, function and evolution of turtle hemoglobins. II. Electrophoretic studies. Comp. Biochem. Physiol. 23: 449-458.

Troiano JC and Silva MC (1998). Valores hematológicos de referencia en tortuga terrestre argentina (Chelonoidis chilensis chilensis). Analecta Vet. 18: 47-51.

Wood FE and Ebanks GK (1984). Blood cytology and hematology of the green sea turtle, Chelonia mydas. Herpetologica 40: $331-336$. 